\title{
THE IMPACT OF CAPITAL STRUCTURE CHOICE ON FIRM'S FINANCIAL PERFORMANCE: AN EMPIRICAL ANALYSIS OF DELISTED FIRMS IN VIET NAM
}

\author{
NGUYEN VINH KHUONG \\ Nguyen Tat Thanh University, Vietnam - Email: khuongnguyenktkt@gmail.com \\ DINH THI THU THAO \\ Nguyen Tat Thanh University, Vietnam - Email: thuthao160290@gmail.com \\ (Received: September 20, 2016; Revised: October 4, 2016; Accepted: October 10, 2016)
}

\begin{abstract}
The purpose of this study is to examine the impact of capital structure choice on firm's financial performance of delisted companies on the stock market. Based on the data collected from 80 companies delisted from Vietnam stock markets (HNX and HOSE) in the period from 2012 to 2015, using quantitative research methods, we find a correlation between the capital structure and the financial performance of the firms. The study results have some implications for investors and managers in making decisions to optimize their financial performance.
\end{abstract}

Keywords: Capital Structure; financial performance; delisted firms; stock market; Vietnam.

\section{Introduction}

Capital structure decision is the mix of debt and equity that the firms used in its operation (Akhtar \& Javed, 2012). It is the combination of long term debt, short term debt and equity maintained by a firm. Firms often have to make decisions on how to get the most out of the proportion they are using for their capital. How to structure capital is the very first question that financial managers ask themselves before getting into any financial activity.

The strength of financial position of an organization is its financial performance. Financial analysis is the process of identifying the firm's financial strengths and weaknesses by properly establishing the relationship between balance sheet items and the Profit and Loss accounts. In financial analysis, a ratio is often used to evaluate the firm's financial position and performance. A ratio is defined as "the indicated quotient of two mathematical expressions" or "the relationship between two or more things". Ratios help to summarize a large number of financial data and to make judgment about the firm's financial performance (Leon, 2013).

Capital structure refers to the proportion of finances provided to the firm through different sources which may include internal and external financiers. Capital structure of a company may include equity - funds contributed company's owners or shareholders (internal financiers) or debt or hybrid securities provided by creditors (external financiers) to finance the assets of the company. The ratio of total debt to total capital employed is the firm's leverage. In reality, capital structure may be highly complex and include several sources of funds. Much research has been conducted to investigate different aspects of capital structure. Modigliani and Miller (1958) wrote a paper about the irrelevance of the capital structure that enthused researchers to debate on this topic. They proposed that capital structure does not influence the value of the firm in perfect markets. The reasons may include bankruptcy costs, agency costs, taxes and information asymmetry, etc. The trade- 
off theory of capital structure states that a company should choose how much debt and equity financing while creating a balance between costs and benefits. Kraus and Litzenberger (1973) observed a balance between costs of bankruptcy and the tax shield provided by debt. Sometimes the costs of the agency are also considered. The theory may illustrate the differences in debt to equity ratios between different industries but no explanation is provided for the same industry. However, today, capital structure is one of the most important financial decisions for any business organization. This is for two following reasons: (1) the organization needs to maximize returns to various stakeholders; and (2) such decision has a great effect on the firm's value.

Myers (2001) stated that companies with high growth opportunities will have a smaller amount of debt compared to companies with lower growth opportunities. Companies find it too costly to finance projects by using debt (Chen \& Jiang, 2001). Higher growth opportunities increase the likelihood of investing in risky projects or suboptimal. In such a case, debt collection becomes more difficult because debt providers are less likely to get their money back. Therefore, debt suppliers are not willing to lend money to companies that overinvested (Deesomak et al, 2004).

Besides, the impact of the decision will help the firm able to deal with its competitive environment. As defined above, capital structure is a combination of debt and equity that a firm uses to enhance its operation. Thus, firms should build up an appropriate mix of debt and equity to finance their assets.

Due to the lack of a consensus about an optimal capital structure, it is pertinent to examine the effect of debt utilization on firms' performance. Several similar studies were conducted in European countries and the United States. They found contradictory results when Gleason (2000) supported a negative impact of leverage on the profitability of the firm while Roden and
Lewellen (1995), in their study on leveraged buyouts, found a significant positive association between profitability and total debt as a percentage of the total buyoutfinancing package. Accordingly, there is no universal theory about debt-equity choices and different views on financing option are something quite understandable.

The relationship between capital structure and corporate financial performance has been an important issue for both academics and 20 experts in the business world (San, O. T. and Heng, T. B., 2011). While there is a scarcity of statically evidence about the impact of capital structure on corporate financial performance in advanced and developing economics, most of past research on capital structure has always been from the determinants on corporate leverage.

Recently, there have been several studies in Vietnam regarding the determinants of Vietnamese corporate capital structure. The search for factors affecting the capital structure of Vietnam's enterprises has been a hot topic for many authors. For example, Tran Dinh Khoi Nguyen and Ramachandran (2006) studied the capital structure of small and medium enterprises in Vietnam whereas Biger, Nam V. Nguyen, and Quyen X. Hoang (2008) examined the determinants of capital structure of companies in Vietnam. However, no study is conducted for delisted companies on Vietnam stock markets. Delisting means the remove of a listed company from a stock exchange. The number of delisted companies which suffered financial losses and reduced public confidence has increased in recent years.

This study aimed to help company managers make good decisions on the proportions of their capital structure. Taking too much debt for company's operation can put the company's future at risk, and thus can make the company go bankrupt. This study, therefore, seeks to provide and update corporate managers with new knowledge to make proper decisions on the company's performance. 
Most famous studies of financial exhaustion were conducted in the US and European countries. In Viet Nam, this is still a new topic and was conducted by some Vietnamese researchers. However, no research on delisted companies was implemented. The number of delisted companies has increased in recent years and consequently, led to financial losses and reduced public confidence. Therefore, the authors carried out this study to assess the impact of the capital structure on the performance of companies delisted from the Vietnam Stock Exchange.

To the author's knowledge, there was little research on similar topic about the lagged values towards the performance of Vietnamese firms. Hence, this research will explore to what extent debt will influence a firm's performance. In addition, it is interesting to differentiate short- term debt, long- term debt and total debt effects since they have different risk and return profiles.

\section{Literature Review and Hypotheses}

The relationship between capital structure and firm value has been the main subject of many debates both theoretically and empirically. Much research has been done about the impact of capital structure choice on firms' financial performance. Strong debates regarding capital structure and firm performance have been started since Miller and Modigliani (1958) introduced their influential work. They argued that firm value was independent of firm capital structure and that using debt or equity had no material effect on firm value. In the paper, they relaxed their assumption by incorporating corporate tax benefits as determinants of the firm's capital structure. They proposed that firms should employ as much debt capital as possible to achieve optimal capital structure

Static trade off-theory states that the firm's capital structure decisions involve a tradeoff between the tax benefits of debts and the cost of financial distress. Thus, firms should choose an optimal capital structure that trades off the marginal benefits and the costs of debt (Myers, 1984). Agency cost theory initiated by Jensen and Meckling (1976). Agency costs rise from the separation of ownership and the control and conflicts of interest among agents (managers), shareholders, and debt holders. According to this theory, an optimal capital structure can be obtained by trading off the agency cost of debt against the benefit of debt. Agency costs are costs arising due to conflicts of interest. The pecking order theory developed by Myers and Majluf (1984) stated that capital structure is determined by the firm's desire to finance new investments, first internally generated funds, then with low-risk debt, and finally if all fails, with equity finance.

Some assumptions put a ceiling on Modigliani and Miller's theorem of debt peripheral nature, which do not exist in reality. When these assumptions are not taken into account, then the choice of the capital structure becomes very indispensable. Fischer et al. (1989) argued that with the passage of time corporations are inclined towards their preferred leverage range by issuing new securities and equity.

Return on assets (ROA): ROA is an indicator assessing the profitability of the business assets. It is calculated by the formula ROA $=$ Profit after tax $/$ Total Assets. The index shows a property contract could create as many profitable contracts. Profit is the ultimate goal of all companies and serves as a basis for investors to assess the performance of a business. However, to assess the profitability of each business, and to compare between businesses, we need to compare profit with other indicators such as total assets, equity or revenue. Maybe benefit higher profit this year than last year does not mean it is a good sign for further consideration must also increase profits are commensurate with the increase in total assets of the enterprise has invested or not. ROA is an important financial indicator to assess this aspect. A low ROA will affect the firm's solvency and increase its risk of going bankrupt. Thus, ROA is referred to as a 
dependent variable in the study.

Total debts to assets ratio (TDTA): TDTA is calculated by dividing total debt by total assets. By this way, (Holz, 2002) found that capital structure (debt ratio) positively correlated with the firm's performance, the result is ascribed to the managers' willing to finance a project by borrowing money and using them effectively to optimize the firm's performance.

H1: Total debt to assets ratio has a negative (-) correlation with the financial performance

Short-term debt to total assets ratio (SDTA): SDTA is short-term debt divided by total assets. This indicator provides information about a firm's ability to meet short-term financial obligations. It shows how a company uses its short-term debts to make profits. Dessi R.and Donald R., 2003 found that financial leverage positively affects the expected performance. The results show that low growth firms tend to borrow money to utilize their expected growth targets and then invest the money on profitable projects; thus, increase the firms' performance. (Margaritis, D. and Psillaki, M., 2010). The findings also proved that financial leverage (debt ratio) positively and significantly correlated with the firm's performance (added value, labor, and capital).

H2: Short term debt to total assets ratio has a negative (-) correlation with the financial performance

Long-term debt to total assets ratio (LDTA): LDTA is an indicator of financial leverage. It shows a company's ability to pay off its liabilities with its assets. This enables comparisons of leverage to be made across different companies. LDTA is calculated by dividing long debt by total assets. The study used debt to equity ratio as financial leverage indicator and earnings to the market value of common stock as a performance indicator. Results revealed that leverage has positively effects on firm's value and proved the traditional assumption that shareholders wealth can be enhanced by using outside financing.

H3: Long-term debt to total assets ratio has a negative (-) correlation with the financial performance

Business risks (RISK): Many theoretical studies have shown that business risk or earnings volatility is one of the factors that affect the capital structure of the business. According to the tradeoff theory of capital structure and the pecking order theory, firms with high volatility in income face greater risk in the payment of debts. This implies that firms with high earnings volatility will borrow less and prefer the internal funds. Thus, a negative relationship between business risk or earnings volatility and financial performance is expected. The empirical studies supporting this view include Booth et al. (2001), Fama and French (2002), Jong et al. (2008), Sharif et al. (2012). The author suggests the following hypothesis:

H4: Business risks has a negative (-) correlation with the financial performance

Asset tangibility (TANG): TANG is an asset that has a physical form. Asset tangibility changes over time for reasons beyond the control of firms and financiers. When asset tangibility is high, managers have heightened incentives to perform because the firm's liquidation/reorganization becomes a more credible threat. The effect of asset tangibility on investment performance under external financing is magnified when firms are near distress (Murillo Campello, 2007).

H5: Asset tangibility has a positive (+) correlation with the financial performance

Firm size (SIZE): According to the tradeoff theory of capital structure, large-scale enterprises usually are able to get more loans than small-scale ones. Specifically, it costs more for small businesses to mobilize external capital compared to big ones due to asymmetric information. In other words, big enterprises prevail over small ones when accessing the capital markets. This shows a positive correlation between financial performance and company size. This view is 
supported by many empirical studies in various countries, including studies conducted by Booth et al. (2001), Faris (2010), and Bambang et al. (2013). Based on the tradeoff theory of capital structure and empirical studies' results obtained by national and international researchers, the authors suggest the following hypothesis:

H6: Firm size has a positive (+) correlation with the financial performance

Liquidity (LIQ): LIQ is calculated by current ratio. Liquidity's relevance is better explained by using free cash flow theory, agency cost of debt and trade off theory. According to pecking order theory, in search for capital fund, companies prefer internal financing from retained earnings to external financing. As a result, the demand for external capital will not be crucial for companies with high ability of generating retained earnings if their current assets suffice for financing the investment. This indicates a negative correlation between liquidity and financial performance. Empirical research supporting this view includes studies done by Eriotis et al. (2007), Singhania et al. (2010). However, the tradeoff theory of capital structure states that firms with high liquidity generally maintain a higher debt ratio, indicating a positive correlation between liquidity and capital structure. Based on the pecking order theory and empirical results of previous research, the authors make the following hypothesis:

H7: Liquidity has a negative (-) correlation with financial performance

Growth opportunities (GROWTH): GROWTH variable is calculated by the ratio of sales growth to total assets growth. Relevant theoretical support is provided by signaling theory, trade-off theory and pecking order theory and expected correlation with leverage is negative in literature. The theoretical study agreed that growth opportunities are associated with financial performance. The trade-off theory of capital structure suggests that firms with higher growth opportunities typically maintain a low debt ratio, which indicates a negative correlation between growth opportunities and financial performance. Empirical studies supporting this view include ones done by Eriotis et al (2007), Gurcharan (2010). On the other hand, the pecking order theory believes that firms with high growth opportunities are expected to demand more debt financing in the future.

H8: Growth opportunities has a positive

(+) correlation with financial performance

\section{Data and Variables}

\subsection{Sample Description}

In this study, the data was collected from 80 delisted companies on Vietnam stock markets (HNX and HOSE) in the period from 2012 to 2015. For some enterprises, collected data consists of the balance sheet and annual P $\& \mathrm{~L}$ statements. In the sample selection process, 192 observations were collected.

\subsection{Variables}

Our dependent variable is the return on assets. This is the key variable to assess financial performance, which is defined as the ratio of profit after tax divided by the firm's total assets.

$$
\mathrm{ROA}=\text { Profit after tax /Total Assets }
$$

Based on previous studies, we use eight independent variables for this research. They are: total debt to total assets, short-term debt to total assets, long-term debt to total assets, business risks, firm performance, asset tangibility, firm size, liquidity, and growth opportunities. As far as independent variables are concerned, we have selected several proxies that appear in the empirical literature.

$\checkmark$ TDTA $=$ Total debt $/$ Total assets

$\checkmark$ STDTA $=$ Short-term debt/ Total assets

$\checkmark$ LTDTA $=$ Long-term debt/ Total assets

$\checkmark$ RISK $=$ Interest Payments/ Earnings before Interest and Tax

$\checkmark$ TANG $=$ Natural logarithm of Asset tangibility

$\checkmark$ SIZE $=$ Natural logarithm of total assets

$\checkmark$ LIQ $=$ Current Assets/ Current Liabilities

$\checkmark$ GROWTH= Ratio of sales growth to total assets growth 


\section{Research Methodologies}

Since the sample contains data across firms and at different time, the cross-sectional method is employed. The analysis process includes two stages. In the first stage, we conduct regressions of all determinants related to a capital structure (total debt to total assets, short-term debt to total assets, and long-term debt to total assets) about firm performance. In the second stage, we add a dummy variable (DUM) to evaluate the differences in capital structure and its determinants between (TDTA $<0.5739)$ and (TDTA $>0.5739$ ).

This regression model can be specified as follows:

\section{Research model:}

Model 1 is applicable to delisted companies on Viet Nam market stock:

$\mathrm{ROA}_{\mathrm{i}, \mathrm{t}}=\alpha+\beta_{1} \mathrm{SDTA}_{\mathrm{i}, \mathrm{t}}+\beta_{2} \mathrm{LDTA}_{\mathrm{i}, \mathrm{t}}+\beta_{3} \mathrm{RISK}_{\mathrm{i}, \mathrm{t}}+\beta_{4} \mathrm{TANG}_{\mathrm{i}, \mathrm{t}}+\beta_{5} \mathrm{SIZE}_{\mathrm{i}, \mathrm{t}}+\beta_{6} \mathrm{LIQ}_{\mathrm{i}, \mathrm{t}}+$ $\beta_{7}$ GROWTH $_{\mathrm{i}, \mathrm{t}}+\varepsilon_{\mathrm{i}, \mathrm{t}}$

Model 2 is applicable to companies delisted from VN market stock:

ROA $_{i, t}=\alpha+\beta_{1}$ TDTA $_{i, t}+\beta_{2}$ RISK $_{i, t}+\beta_{3}$ TANG $_{i, t}+\beta_{4}$ SIZE $_{i, t}+\beta_{5}$ LIQ $_{i, t}+\beta_{6} \mathrm{GROWTH}_{i, t}+\varepsilon_{i, t}$

Model 3 is applicable to evaluate the differences in the financial performance (TDTA<0.5739):

ROA $_{i, t}=\alpha+\beta_{1}$ TDTA $_{i, t}+\beta_{2}$ RISK $_{i, t}+\beta_{3}$ TANG $_{i, t}+\beta_{4}$ SIZE $_{\mathrm{i}, \mathrm{t}}+\beta_{5} \mathrm{LIQ}_{\mathrm{i}, \mathrm{t}}+\beta_{6} \mathrm{GROWTH}_{\mathrm{i}, \mathrm{t}}+\mathrm{DUM}_{1}+\varepsilon_{\mathrm{i}, \mathrm{t}}$

Model 4 is applicable to evaluate the differences in the financial performance (TDTA>0.5739):

$\mathrm{ROA}_{\mathrm{i}, \mathrm{t}}=\alpha+\beta_{1} \mathrm{TDTA}_{\mathrm{i}, \mathrm{t}}+\beta_{2} \mathrm{RISK}_{\mathrm{i}, \mathrm{t}}+\beta_{3} \mathrm{TANG}_{\mathrm{i}, \mathrm{t}}+\beta_{4} \mathrm{SIZE}_{\mathrm{i}, \mathrm{t}}+\beta_{5} \mathrm{LIQ}_{\mathrm{i}, \mathrm{t}}+\beta_{6} \mathrm{GROWTH}_{\mathrm{i}, \mathrm{t}}+\mathrm{DUM}_{2}+\varepsilon_{\mathrm{i}, \mathrm{t}}$

\begin{tabular}{|c|c|c|c|c|}
\hline \multirow{2}{*}{ No. } & \multicolumn{2}{|c|}{ Independent variables } & \multirow{2}{*}{ Hypothesis } & \multirow{2}{*}{ Theories } \\
\hline & Name & Sign & & \\
\hline 1 & Total debt to total assets & TDTA & $(-)$ & $\begin{array}{l}\text { Bankruptcy cost, trade off theory, } \\
\text { pecking order theory }\end{array}$ \\
\hline 2 & $\begin{array}{c}\text { Short term debt to total } \\
\text { assets }\end{array}$ & SDTA & $(-)$ & $\begin{array}{c}\text { Bankruptcy cost, trade off theory, } \\
\text { pecking order theory }\end{array}$ \\
\hline 3 & $\begin{array}{l}\text { Long term debt to total } \\
\text { assets }\end{array}$ & LDTA & $(-)$ & $\begin{array}{c}\text { Bankruptcy cost, trade off theory, } \\
\text { pecking order theory }\end{array}$ \\
\hline 4 & Business risks & RISK & $(-)$ & Agency theory, bankruptcy cost \\
\hline 5 & Asset tangibility & TANG & $(+)$ & Bankruptcy cost \\
\hline 6 & Firm size & SIZE & $(+)$ & Agency cost of debt \\
\hline 7 & Liquidity & LIQ & $(-)$ & $\begin{array}{c}\text { Free cash flow theory, agency cost } \\
\text { of debt, trade off theory }\end{array}$ \\
\hline 8 & Growth opportunities & GROWTH & $(+)$ & Agency theory \\
\hline
\end{tabular}

\section{Research results}

\subsection{The reality of the delisted companies} on Vietnam stock markets

The number of delisted companies has increased in recent years. Specifically, from

\section{Table 1}

Statistics of the delisted company annually

\begin{tabular}{|c|c|c|c|c|}
\hline Year & $\mathbf{2 0 1 2}$ & $\mathbf{2 0 1 3}$ & $\mathbf{2 0 1 4}$ & Total \\
\hline Number of companies delisted & 18 & 46 & 32 & 96 \\
\hline
\end{tabular}

2012 to June 30, 2015, the number of delisted companies is 120 , of which 78 companies delisted from the HNX and 42 companies from the HOSE for various reasons (follow on the websites: www.hnx.vn, and www.hsx.vn). 


\subsection{Results}

Table 2

Descriptive statistics of sample variables

\begin{tabular}{|c|l|c|c|c|c|}
\hline Variable & Obs & Mean & Std.Dev & Min & Max \\
\hline ROA & 192 & -0.1059896 & 0.2107555 & -2.21 & 0.14 \\
\hline TDTA & 192 & 0.7635938 & 0.3495294 & 0.04 & 2.69 \\
\hline SDTA & 192 & 0.6121555 & 0.3278615 & 0.04 & 2.04 \\
\hline LDTA & 192 & 0.151097 & 0.227315 & -.021 & 1.66 \\
\hline RISK & 192 & 0.6683333 & 11.12382 & -21.01 & 121.51 \\
\hline TANG & 192 & 0.4729167 & 0.4629813 & 0 & 2.39 \\
\hline SIZE & 192 & 26.32849 & 1.216191 & 23.46 & 29.38 \\
\hline LIQ & 192 & 1.386146 & 2.133767 & 0.1 & 18.13 \\
\hline GROWTH & 192 & -0.1256771 & 0.5901447 & -1.07 & 3.37 \\
\hline
\end{tabular}

The mean of the variable explains the average profit with respect to total assets of the companies in the sample of this study.
Table 2 shows that companies in this study use a maximum of $14 \%$ of profit to finance their company's assets.

Table 3

Pearson correlation coefficient matrix

\begin{tabular}{|l|r|r|r|r|r|r|r|r|r|}
\hline ROA & \multicolumn{1}{c|}{ ROA } & TDTA & STDTA & LTDTA & GROWTH & SIZE & LIQ & RISK & TANG \\
\hline TDTA & -0.6151 & 1.0000 & & & & & & & \\
\hline SDTA & -0.4180 & 0.7762 & 1.0000 & & & & & & \\
\hline LDTA & -0.3432 & 0.4184 & -0.2478 & 1.0000 & & & & & \\
\hline $\begin{array}{l}\text { GROW } \\
\text { TH }\end{array}$ & -.2542 & -0.1896 & -0.1770 & -0.0361 & 1.0000 & & & & \\
\hline SIZE & -0.0297 & 0.4186 & 0.1720 & 0.3940 & -0.0166 & 1.0000 & & & \\
\hline LIQ & -0.1422 & -0.4878 & -0.4063 & -0.1643 & 0.0891 & -0.2554 & 1.0000 & & \\
\hline RISK & 0.0465 & 0.0169 & -0.1101 & 0.1850 & 0.0463 & 0.0449 & -0.0174 & 1.0000 & \\
\hline TANG & 0.0006 & -0.0846 & -0.2716 & 0.2616 & -0.0175 & -0.2848 & -0.0497 & 0.1166 & 1.0000 \\
\hline
\end{tabular}

To test the correlation between variables, the Pearson correlation coefficient was employed. This test measured how variables move from each other. The correlation between variables in Table 3 gives a first indication of the sign and influence of the variables in determining leverage. The correlation of -0.6151 for TDTA and ROA indicates a negative correlation between the variables. The same applies for the SDTA, LDTA and SIZE with a correlation of $0.4180,-0.3432$ and -0.0297 respectively. GROWTH, LIQ and RISK are positive with a correlation of $0.2542,0.1422$ and 0.0465 respectively. The same applies for the TANG with a correlation of 0.0006 . 


\section{Table 4}

The regression results of model 1 (Pooled OLS)

\begin{tabular}{|c|c|c|c|c|}
\hline \multirow[b]{2}{*}{ Variables } & \multicolumn{2}{|c|}{ Regression Model 1} & \multicolumn{2}{|c|}{ Regression Model 2} \\
\hline & Coef. & $\mathbf{P}>|\mathbf{t}|$ & Coef & $\mathbf{P}>|\mathbf{t}|$ \\
\hline SDTA & $* * *-0.4247214$ & 0.000 & & \\
\hline DTA & $* *-0.6477301$ & 0.014 & & \\
\hline TDTA & & & $* * *-0.476747$ & 0.002 \\
\hline GROWTH & $* * 0.0465444$ & 0.015 & $* * 0.0440634$ & 0.019 \\
\hline SIZE & $* * * 0.05929$ & 0.009 & $* * * 0.0434308$ & 0.001 \\
\hline LIQ & $* *_{-} 0.0157777$ & 0.032 & $*_{-} 0.0187783$ & 0.071 \\
\hline RISK & $* * 0.0013019$ & 0.018 & $* * * 0.0007675$ & 0.006 \\
\hline TANG & $* * 0.0393713$ & 0.426 & -0.0036955 & 0.853 \\
\hline CONS & $* *_{-} 1.300911$ & 0.016 & $* * *_{-} 0.852614$ & 0.001 \\
\hline Observations & 192 & & 192 & \\
\hline R-squared & $51.93 \%$ & & $48.51 \%$ & \\
\hline
\end{tabular}

$\mathrm{ROA}_{\mathrm{i}, \mathrm{t}}=\alpha-0.4247 \mathrm{SDTA}_{\mathrm{i}, \mathrm{t}}-0.6477 \mathrm{LDTA}_{, \mathrm{t}+}$ 0.0465GROWTH $\mathrm{GR}_{\mathrm{i}, \mathrm{t}}$ 0.0593SIZE $\mathrm{i}_{\mathrm{t}, \mathrm{t}}-0.0158 \mathrm{LIQ}_{\mathrm{i}, \mathrm{t}+}$ 0.0013 RISK $_{\mathrm{i}, \mathrm{t}}+0.0394 \mathrm{TANG}_{\mathrm{i}, \mathrm{t}}-1.3009+\varepsilon_{\mathrm{i}, \mathrm{t}}$

ROA $_{i, t}=\alpha-0.4767$ TDTA $_{i, t}+0.0441$ GROWTH $_{i, t}+0.0434$ SIZE $_{i, t}-0.0188$ LIQ $_{\mathrm{i}, \mathrm{t}}+0.0008 \mathrm{RISK}_{\mathrm{i}, \mathrm{t}}-$ $0.8526+\varepsilon_{\mathrm{i}, \mathrm{t}}$

Table 5

The regression results of model 3 (TDTA < 0.5739)

\begin{tabular}{lrr}
\hline \multicolumn{1}{c}{ Independent variables } & \multicolumn{1}{c}{ Coef. } & $\mathbf{P}>|\mathbf{t}|$ \\
\hline TDTA & $* * *_{-} 0.6479297$ & 0.001 \\
GROWTH & $* * 0.0440464$ & 0.014 \\
SIZE & $* * * 0.0315508$ & 0.002 \\
LIQ & $* *-0.0161191$ & 0.038 \\
RISK & 0.0004242 & 0.246 \\
TANG & 0.0061172 & 0.755 \\
DUM1 & $* * *-0.2131848$ & 0.008 \\
CONS & $* *-0.3561492$ & 0.014 \\
\hline Observations & 192 & \\
R-squared & $58.18 \%$ & \\
\hline P_Value $>\mathrm{X}^{2}=0.0000 * * *$ & & \\
\hline
\end{tabular}




\section{Table 6}

The regression results of model 4 (TDTA > 0.5739)

\begin{tabular}{lrr}
\hline \multicolumn{1}{c}{ Independent variables } & \multicolumn{1}{c}{ Coef. } & $\mathbf{P}>|\mathbf{t}|$ \\
\hline TDTA & $* * *_{-} 0.6479297$ & 0.001 \\
GROWTH & $* * 0.0440464$ & 0.014 \\
SIZE & $* * * 0.0315508$ & 0.002 \\
LIQ & $* *-0.0161191$ & 0.038 \\
RISK & 0.0004242 & 0.246 \\
TANG & 0.0061172 & 0.755 \\
DUM2 & $* * * 0.2131848$ & 0.008 \\
CONS & $* *-0.569334$ & 0.014 \\
\hline Observations & 192 & \\
R-squared & $58.18 \%$ & \\
\hline P_Value $>\mathrm{X}^{2}=0.0000 * * *$ & & \\
\hline
\end{tabular}

ROA $_{i, t}=\alpha-0.4247$ SDTA $_{i, t}-0.6477$ LDTA $_{, t+} 0.0465$ GROWTH $_{i, t+} 0.0593$ SIZE $_{i, t}-0.0158$ LIQ $_{i, t+}$ 0.0013 RISK $_{\mathrm{i}, \mathrm{t}}+0.0394 \mathrm{TANG}_{\mathrm{i}, \mathrm{t}}-1.3009+\varepsilon_{\mathrm{i}, \mathrm{t}}$

ROA $_{\mathrm{i}, \mathrm{t}}=\alpha-0.4767 \mathrm{TDTA}_{\mathrm{i}, \mathrm{t}+} 0.0441 \mathrm{GROWTH}_{\mathrm{i}, \mathrm{t}+} 0.0434 \mathrm{SIZE}_{\mathrm{i}, \mathrm{t}}-0.0188 \mathrm{LIQ}_{\mathrm{i}, \mathrm{t}+} 0.0008 \mathrm{RISK} \mathrm{i}_{\mathrm{t}, \mathrm{t}}-$ $0.8526+\varepsilon_{\mathrm{i}, \mathrm{t}}$

Table 4 above presents the results of the Pooled Regression Models (Model 1and Model 2) estimated to examine the impact of capital structure on financial performance (ROA) of selected companies controlling the effect of firm-specific variables.

Regression model 1 tests the relationship between capital structure measured by ratios of STD to total assets and LTD to total assets and firms' financial performance measured by return on assets (ROA). On the other hand, regression model 2 estimated the relationship between capital structure measured by total debt to total assets ratio (TDTA) and firms' financial performance measured by return on assets (ROA). The overall explanatory powers of the two regression models (Model 1 and Model 2) are $51.93 \%$ t and $48.51 \%$ respectively. This implies that volatility of the variables used in Model 1 and Model 2 causes $54.25 \% \mathrm{t}$ and $54.83 \%$ changes in dependent variables respectively. The $\mathrm{P}$ - values for model 1 and for model 2 prove the validity of the estimated models. Also, the coefficients are statistically significant at $1 \%$ level of significance.

As revealed in Table 4 above, the result of regression model 1 , model 2 indicates a significant negative correlation between capital structure and financial performance measured, which implies that an increase in debt is associated with a decrease in financial performance (ROA). This is because longterm debts are relatively more expensive, and therefore using more long-term debts could lead to low profitability. This result is consistent with the findings of previous studies such as research by (Abor, 2007; Gansuwan \& Onel; Zeitun \& Tian, 2007). However, the negative and significant relationship of SDTA does not support Abor's (2005) argument that short-term debt increases a firm's performance because it could be due to relative lower cost and lowinterest rate.

Firm leverage for the sample study effects negatively and statistically significant at $1 \%$ on firm performance (ROA) of Vietnam's 
delisted companies. Therefore, this study confirms a negative correlation between firm leverage and firm performance. This result can be interpreted that high leverage companies would have less performance. In other words, the debt level is higher than optimized level and compared to tax shield, incensement of financial distress costs has more significance. Other reasons may include Informational asymmetry and high costs of external resources and a lack of efficient financial markets. The outcome provides evidence to support the pecking order theory. Pecking order theory states that higher profitability would enable the company to retain more earnings which is the preferable source of funding, and as such, the amount of leverage needed by the company should decrease. This negative relationship indicates that Vietnam's delisted companies do not use debt to maximize their performance.

Growth opportunities: The regression result shows a positive but insignificant correlation between a firm's growth opportunities and its performance. Although the expected sign positive is confirmed, the hypothesis is rejected on the practical of its non-significance. The positive relationship might be a good alternative for the firm because investors and shareholders often choose to invest in lucrative projects.

Firm size: The result from pooled OLS model shows that firm size is positive and has a highly significant relationship with performance of Vietnam's delisted companies. The significance of firm size on performance indicates that large firms can earn high returns compared to smaller ones, mostly due to the diversification of investment and economic scale. The larger the company is, the higher its performance. This conclusion supported by trade-off theory, which stated that size reflects greater diversification, economics of scale production, greater access to new technology and cheaper sources of funds.

Liquidity: A result from Pooled OLS models is against the theoretical expectation because of a negative and significant relationship between firm liquidity and performance of Vietnam's delisted companies. Therefore, the researcher accepts the hypothesis because of the insignificant and inverse relationship.

Business risk: This study confirms panel data results for the analysis method of Pooled OLS model. The results show a positive and significant impact on the performance of Vietnam's delisted companies. Therefore, the researcher accepts the previous hypothesis and Vietnam's delisted companies may reduce their risk by increasing and diversifying its operation. This study is supported by agency theory which states that the required rate return from investors should be suitable to their risk in the firm.

\section{Conclusion}

The capital structure decision is important for any business company because of its crucial role in maximizing the returns for company's various stakeholders and its great impact on the company's ability to tackle their competitive and dynamic business environment.

In this study, analysis is conducted to investigate how some specific firm characteristics determine the firm's capital structure. We use the data collected from financial statements of 80 companies delisted from Vietnam stock exchange during 2012 2015. According to the results, there is a negative correlation between all capital structures variables (short term debt to total assets, long-term debt to total assets, and total debt to total assets) and their firm performance measures (return on assets). Size and Risk appear to maintain a positive relation. The result also proves that an increase in leverage negatively affects the firm's performance. The outcome provides evidence to support the pecking order theory of capital structure which suggests that profitability of a firm initially relies on cheaper internally-generated funds before seeking for external finances. Therefore, it is expected that high lucrative production firms 
require less debt finance. Moreover, it also supports for the proposition that owing to agency conflicts; companies use more leverage, and thus negatively affect their performance.

The research findings assisted the pecking order theory, trade-off theory, and agency cost theory. The study shows that sign for expected value is confirmed by actual relation of the model under the study of the firm performance (ROA) measures in regression model result.

This study paves the way for upcoming studies to investigate capital structure theories on valuable companies listed on Vietnam stock markets and valuable sectors of Viet Nam.

\section{Limitations}

Apart from some contributions, this research also has some limitations. Within the research framework, we did not mention some other theories concerning the capital structure which also have influence on the choice for debt or equity. During the data collection process, we have used some external database whose reliability is not definitely confirmed. The last limitation may be the generalizability of the results to specific companies. Articles by Antoniou et al. (2002) and Deesomak et al. (2004) indicate that the differences in capital structure among companies do not only cause by firm's specific factors but also by the environment in which the company operates. Therefore, companies would find it is hard to apply these research findings to their specific situation if they are not established in Vietnam. This is because the choices of companies for capital structure vary from country to country and region to region.

\section{Suggestions for future research}

The research findings and limitations may be useful for further research to examine the effect of a financial crisis. The data of this study is updated until sometime after the 2008 financial crisis and compares the results concluded by studies before and after the crisis. The data, therefore, could be utilized to help address changes in the capital structure during crisis. Another suggestion would be an emphasis on the use of different data necessary for good proxies of the variables. For future research, it might be meaningful to use market value instead of book value. Previous research in Dutch companies done by Chen et al. (1999) showed a difference in the results due to using book value and market value. It is also interesting if future research investigates how a higher dilution percentage of preferred shares might affect the leverage. By using a higher percentage of dilution for preferred shares, companies enhance the ability to protect themselves against loss of corporate control. By adding specific variables to countries, we can address the factors that influence the capital structure in different countries. The results are of more concern for specific companies. For example, future research could investigate the differences between Laos and Cambodia. Additionally, future studies may also increase panel size of companies delisted from Vietnam stock markets by using more companies with longer period data

\section{References}

Abor, J. (2005). The effect of capital structure on profitability: an empirical analysis of listed firms in Ghana. The journal of risk finance, $6(5), 438-445$.

Ahmad, Z., Abdullah, N. M. H., \& Roslan, S. (2012). Capital structure effect on firms performance: Focusing on consumers and industrials sectors on Malaysian firms. International review of business research papers, 8(5), $137-155$.

Akhtar S., \& Javed B., 2012. Interrelationships between capital structure and financial performance, firm size and growth: comparison of industrial sector in KSE. European Journal of Business and Management, 4(15), 2222-1905. 
Booth, L., Aivazian, V., Demirguc-Kunt, A., \& Maksimovic, V. (2001). Capital structures in developing countries. The journal of finance, 56(1), 87-130.

Campello, M. (2007). Asset tangibility and firm performance under external financing: evidence from product markets. Available at SSRN 971170.

Chen, L. H., \& Jiang, G. J. (2001). The determinants of dutch capital structure choice (pp. 1-25). University of Groningen.

Chen, L. H., Lensink, B. W., \& Sterken, E. (1999). The determinants of capital structure: Evidence from Dutch panel data. University of Groningen.

De Jong, A., Kabir, R., \& Nguyen, T. T. (2008). Capital structure around the world: The roles of firm-and countryspecific determinants. Journal of Banking \& Finance, 32(9), 1954-1969.

Deesomsak, R., Paudyal, K., \& Pescetto, G. (2004). The determinants of capital structure: evidence from the Asia Pacific region. Journal of multinational financial management, 14(4), 387-405.

Dessí, R., \& Robertson, D. (2003). Debt, incentives and performance: Evidence from UK panel data. The Economic Journal, 113(490), 903-919.

Eriotis, N., Vasiliou, D., \& Ventoura-Neokosmidi, Z. (2007). How firm characteristics affect capital structure: an empirical study. Managerial Finance, 33(5), 321-331.

Fama, E. F., \& French, K. R. (2002). Testing trade-off and pecking order predictions about dividends and debt. Review of financial studies, 15(1), 1-33.

Faris, A. S. (2010). Determinants of capital structure choice: A case study of Jordanian Industrial Companies. AnNajah University Journal for Research, 24(8), 2457-2494.

Fischer, E. O., Heinkel, R., \& Zechner, J. (1989). Dynamic capital structure choice: Theory and tests. The Journal of Finance, 44(1), 19-40.

Gleason, K. C., Mathur, L. K., \& Mathur, I. (2000). The interrelationship between culture, capital structure, and performance: evidence from European retailers. Journal of Business Research, 50(2), 185-191.

Gurcharan, S. (2010). A review of optimal capital structure determinant of selected asean countries. International Research Journal of Finance and Economics, 47, 30-41.

Holz, C. A. (2002). The impact of the liability-asset ratio on profitability in China's industrial state-owned enterprises. China Economic Review, 13(1), 1-26.

Jensen, M. C. (1986). Agency cost of free cash flow, corporate finance, and takeovers. Corporate Finance, and Takeovers. American Economic Review, 76(2), 323-329.

Jensen, M. C., \& Meckling, W. H. (1976). Theory of the firm: Managerial behavior, agency costs and ownership structure. Journal of financial economics, 3(4), 305-360.

Kraus, A., \& Litzenberger, R. H. (1973). A state-preference model of optimal financial leverage. The journal of finance, 28(4), 911-922.

Leon, S. A. J. (2013). The impact of Capital Structure on Financial Performance of the listed manufacturing firms in Sri Lanka. Global Institute for Research \& Education, 2(5), 56-62.

Margaritis, D., \& Psillaki, M. (2010). Capital structure, equity ownership and firm performance. Journal of Banking \& Finance, 34(3), 621-632.

Modigliani, F., \& Miller, M. H. (1958). The cost of capital, corporation finance and the theory of investment. The American economic review, 48(3), 261-297.

Myers, S. 2001. Capital Structure. Journal of Economics Perspectives, 15(2), 297-355.

Myers, S. C. 1984. Capital structure puzzle. The Journal of Finance, 39(3), 575-592.

Myers, S. C., \& Majluf, N. S. (1984). Corporate financing and investment decisions when firms have information that investors do not have. Journal of financial economics, 13(2), 187-221. 
Nahum, B., Nam, N. V. \& Quyen, H. X. (2008). The determinants of capital structure:evidence from Vietnam, AsiaPacific Financial Markets: Integration, Innovation and ChallengesInternational Finance Review, 8, 307-326.

Nguyen, T. D. K., \& Ramachandran, N. (2006). Capital structure in small and medium-sized enterprises: the case of Vietnam. ASEAN Economic bulletin, 23(2), 192-211.

Önel, Y. C., \& Gansuwan, P. (2012). The Influence of Capital Structure on Firm Performance: A quantitative study of Swedish listed firms.

Paudyal, K., Guney, Y., \& Antonious, A. (2002). Determinants of Corporate Capital Structure: Evidence from European Countries. Center for Empirical Research in Finance, Department of Economics and.

Roden, D. M., \& Lewellen, W. G. (1995). Corporate capital structure decisions: evidence from leveraged buyouts. Financial Management, 76-87.

San, O. T., \& Heng, T. B. (2011). Capital structure and corporate performance of Malaysian construction sector. International Journal of Humanities and Social Science, 1(2), 28-36.

Sharif, B., Naeem, M. A., \& Khan, A. J. (2012). Firm's characteristics and capital structure: A panel data analysis of Pakistan's insurance sector. African Journal of Business Management, 6(14), 4939.

Singhania, M., \& Seth, A. (2010). Financial leverage and investment opportunities in India: An empirical study. International research Journal of finance and economics, 40(2), 215-226.

Sudiyatno, B. and Sari, S.M. (2013). Determinants of debt policy: An empirical studying Indonesia stock exchange, International Research Journal, 4(1), 98-108.

Zeitun, R., \& Tian, G. G. (2007). Capital structure and corporate performance: evidence from Jordan. Australasian Accounting, Business and Finance Journal, 1(4), 3. 